\title{
Why all John's Friends are Dutch, Not German: On the Determiner-Like Characteristics of the Inflection on the Universal Quantifier in West Germanic
}

\author{
Robert Cirillo \\ University of Amsterdam
}

\begin{abstract}
The word order in a phrase such as all John's friends, in which a universal quantifier is immediately followed by a genitive, is perfectly grammatical in Dutch but unacceptable in German. This article shows that there are three explanations for this difference between the two closely related languages. First, in German, the Saxon Genitive is a true case assigned in Spec, NP. In contrast, in Dutch and English, genitive case cannot be assigned in Spec, NP without a preposition. The Saxon Genitive in these languages is comparable to a possessive adjective that originates as the head of PossP and moves to D. Second, in a definite DP in a Germanic language, either D or Spec, DP must be occupied; if one of these positions is overtly occupied, and if genitive case has already been assigned, the movement of a genitive phrase to D or Spec, DP is unmotivated and causes ungrammaticality. Third, there is evidence that the $-e$ inflection on the universal quantifier alle 'all' in German and Dutch has the characteristics of a determiner.
\end{abstract}

\section{Introduction.}

Unlike English and Dutch, German does not allow a genitive to follow a universal quantifier:

(1) a. all John's friends

b. al Jans vrienden

(Dutch)

c. *all(e) Johanns Freunde

(German)

\footnotetext{
* This article is based to some extent on Cirillo 2015, which derives from a talk given in 2013. However, it represents a significant theoretical departure from the 2013 talk and resulting paper.
} 
There are also differences in the position and in the manner in which genitive case is assigned in the three languages:

(2) a. All friends of John's

b. *All friends John's

c. ?All friends of John

(3) a. *Alle vrienden van Jans

(Dutch)

all friends of John's

b. *Alle vrienden Jans

all friends John's

c. Alle vrienden van Jan

all friends of John

(4) a. *Alle Freunde von Johanns

(German) all friends of John's

b. Alle Freunde Johanns

all friends John's

c. Alle Freunde von Johann

all friends of John

In this article, I demonstrate that these differences are due to the convergence of three facts. First, the Saxon Genitive in German is a true genitive case assigned in Spec, NP, whereas in Dutch and English, in which genitive case cannot be assigned at the N-level without a preposition, the Saxon Genitive is not a case ending but rather a possessive adjective that originates as the head of a Possessive Phrase (PossP) and ends up in D. Second, there is a requirement in the Germanic languages that the D node - that is, D or Spec, DP - be overtly occupied if a DP is definite. If the D node in a definite DP is already overtly occupied and genitive case has already been assigned, there is no motivation for the movement of a genitive phrase to the D-level, as shown in 1c. Third, the -e inflection on the universal quantifier alle 'all' in German and Dutch is a determiner-like element. 
I also show that dative of possession (possessor doubling) constructions common throughout the Germanic languages can be explained within the same framework. Examples of such constructions are given in 5 .

(5) a. Hem z'n boek $^{1}$

(Non-Standard Dutch, den Besten 2006:109)

him his book

'His book'

b. Däm Pitter sing Frönde (Kölsch, spoken in and around Cologne) the.DAT Peter his friends

'Peter's friends'

c. Per sitt hus

(Norwegian)

Peter his house

'Peter's house'

d. Dem Mann sein Hut the.DAT man his hat

'The man's hat'

The organization of the article is as follows: In section 2, I lay out my theoretical foundations and assumptions. In section 3, I say a few words about the Saxon Genitive and also non-Saxon genitive phrases, and about how the genitive case is assigned in the West Germanic languages. In section 4, I discuss the D-position in the West Germanic languages if a universal quantifier is involved. In section 5, I offer my analysis of the data provided in the introduction. Section 6 covers possessive dative (possessor doubling or dative of possession) constructions. Section 7 presents a summary and some proposals for further research.

\footnotetext{
${ }^{1}$ It is the use of a pronoun such as hem in the possessor position that renders this phrase nonstandard. The use of a nonpronominal, such as de jongen $z$ 'n boek lit. 'the boy his book' or Jan z'n boek lit. 'John his book' would be highly colloquial but not ungrammatical. I have used a nonstandard example here only to clearly demonstrate that the possessor is in the dative. Only pronouns are overtly marked for case in Dutch.
} 


\section{Theoretical Foundations.}

2.1. Distinct Analyses of Genitive Phrases and Possessive Adjectives.

Genitive phrases and possessive adjectives in the West Germanic languages have certain characteristics in common. They have similar semantics, as they both indicate possession; they have similar positioning and both indicate definiteness in prenominal position, as illustrated in 6 .
(6) a. John's house...
b. His house...

Because of these commonalities, one might be tempted to analyze genitives and possessive adjectives as belonging to the same syntactic category, and as having the same base position and landing site.

There are, however, several compelling arguments against such a uniform analysis. One argument is that genitives and possessive adjectives are not in the same case. In examples 7a,b from German, the noun Tochter 'daughter' is in the nominative case. Both components of the genitive phrase ihres Vaters 'her father's' in 7a are in the genitive case. However, the possessive adjective seine 'his' in $7 \mathrm{~b}$ is in the nominative case because it must agree in case with the noun it modifies.

(7) a. Sie ist ganz ihres Vaters Tochter. she is totally her.GEN father's daughter

b. Sie ist ganz seine Tochter. she is totally his.NOM daughter

Genitive phrases and possessive adjectives also differ in $\Phi$-feature agreement. The possessive adjective seine 'his' in $7 \mathrm{~b}$ is feminine singular like the noun it modifies. The genitive phrase in 7 a shows no such agreement.

Another major difference between possessive adjectives and genitive phrases is that they differ in positioning and definiteness. Possessive adjectives in German are definite and prenominal. Genitives need not be either. The genitive in $8 \mathrm{c}$, for example, is postnominal and the phrase is indefinite. 
(8) a. Johanns Freunde...

(definite)

John's friends

b. Seine Freunde...

his friends

(definite)

c. Freunde Johanns...

(indefinite)

friends John's

'Friends of John's'

d. *Freunde seine...

friends his

Possessive adjectives are also not interchangeable with other possessive or genitive forms. This is illustrated in the contrast between $9 \mathrm{a}, \mathrm{b}$ and $9 \mathrm{c}, \mathrm{d}$ :

(9) a. That is Mary's book.

b. That book is Mary's.

c. That is her book.

d. *That book is her.

Unlike genitive phrases, which are typically DPs in the genitive case, possessive adjectives behave like heads in that they show $\Phi$-feature agreement with all the other heads in the nominal phrase. In the following Italian example, the possessive adjective suoi 'his/her' shows the same inflection for masculine plural as the quantifier, the definite article, the adjective, and the noun:

(10) Tutti i suoi bei quadri...

all the her beautiful paintings

'all her beautiful paintings'

Another difference between possessive adjectives and genitives is illustrated by the fact that in German, a genitive phrase triggers strong/primary morphology on an adjective regardless of whether the adjective is marked for singular or plural number, as shown in 11a,b. A 
possessive adjective, however, triggers strong/primary morphology if it is singular but weak/secondary morphology if it is plural, as in $11 \mathrm{c}, \mathrm{d}$.

(11) a. Goethes schönste/*schönsten Gedichte... Goethe's most beautiful poems

b. Goethes schönstes/*schönste Gedicht... Goethe's most beautiful poem

c. Sein schönstes/*schönste Gedicht... his most beautiful poem

d. Seine schönsten/*schönste Gedichte... his most beautiful poems

I should point out here that Georgi \& Salzmann (2011) demonstrate that in some ways possessive adjectives in German behave more like determiners than like adjectives. Consider the following examples:

(12) a. Das Trinken des Weins... the drinking the.GEN wine.GEN 'the drinking of the wine'

b. Das Trinken meines Weins... the drinking my.GEN wine.GEN 'the drinking of my wine'

c. Das Trinken guten Weins... the drinking good.GEN wine.GEN 'the drinking of good wine'

One can see here that the genitive ending on the possessive adjective in $12 \mathrm{~b}$ is indeed the same as the ending on the definite article in $12 \mathrm{a}$, while the genitive ending on the adjective in $12 \mathrm{c}$ is [ $\mathrm{n}]$. However, I would suggest that the inflection on the possessive adjective actually depends on its position rather than on its category. That is, if it moves to $\mathrm{D}$, as in $12 \mathrm{~b}$, it takes on the inflection of a determiner. Yet there are instances in which a possessive adjective does not move to D. In those instances, it 
bears the inflection of an adjective. In 13, the possessive adjective meinen 'mine' bears the genitive ending of an adjective, as in $12 \mathrm{c}$, rather than the ending of a determiner seen in $12 \mathrm{a}, \mathrm{b}$.
Ich bin der Grund deines
Lebens
I am the reason your.GEN life.GEN

und du der Grund des meinen.

and you the reason the.GEN mine.GEN

'I am the reason for your life and you (are) the reason for mine.'

Following Sleeman 1996 and Zribi-Hertz 1997, I assume that in this example there is an empty category (an elided noun) following the possessive adjective meinen. The point is that if a possessive adjective moves to $\mathrm{D}$, it behaves like a determiner. In contrast, if it does not move to $\mathrm{D}$, it behaves like an adjective. It is thus positioning that makes the difference, and the term possessive adjective is justified. ${ }^{2}$

Last but not least, a very important difference between German genitives and possessive adjectives lies in their interaction with universal quantifiers, as shown in 14. This interaction is the subject of this article.

(14) a. All(e) seine Freunde... all his friends

b. *All(e) Johannes Freunde... all John's friends

2 The discussion of the category of possessive adjectives could probably continue indefinitely. For example, Dobrovie-Sorin \& Giurgea (2011) show that possessive adjectives behave differently from other adjectives in many respects and would probably object to my using the term possessive adjective. Although their arguments are interesting, I would argue that, as shown in Sleeman 1996, different kinds of adjectives, such as classifying, attributive, denominal and ordinal adjectives, adjectives of quality, etc., behave differently from each other, but they are nonetheless all adjectives. I prefer to follow Cardinaletti 1998 and treat possessive adjectives fundamentally as adjectives. 
Based on this evidence, I follow authors such as Delsing (1993, 1998), den Besten (2006), Práinsson (Thráinsson) (2007), and Norris (2011) in treating genitive phrases as maximal projections base-generated in the specifier position of NP or $\mathrm{nP}$, and possessive adjectives as heads of a PossP located somewhere between $\mathrm{nP}$ and DP.

Before moving on to the next subsection, I should address the positioning of PossP. Assuming that PossP is somewhere above NP, in order to generate constructions with postnominal possessive adjectives, such as the ones found in the Scandinavian languages and Romanian, the head noun must move past the possessive adjective. Of course, the movement of a head across another head causes locality problems. Julien (2005) avoids this problem by treating possessive adjectives as complex heads base-generated in a phrase (here: PossP) that originates in Spec, NP. This enables the head noun to undergo head movement above the possessive adjective without contravening locality-based restrictions on movement. A similar approach is taken by Cinque (2010) in his treatment of adjectives. Cinque places APs in the specifier position of an FP above NP, thereby allowing head nouns to move above adjectives and produce a postnominal adjectival construction. The similarity between Julien's handling of possessive adjectives and Cinque's handling of adjectives is to be expected given the adjectival nature of possessive adjectives. I do not elaborate further on the exact position of PossP; I simply point out that I am open to an approach such as Julien's and do not feel that it is fundamentally incompatible with the one presented here.

\subsection{The Split NP Hypothesis and Genitive Case Assignment.}

Following Abney 1987, Adger 2003, Radford 2004, and Longobardi \& Silvestri 2012, I assume a Split NP Analysis (nP/NP), patterned after the Split VP Analysis that began with Larson 1988. The parallels between Split VP and Split NP are quite striking. For example, both involve raising ( $\mathrm{V}$ to $\mathrm{V}$ and $\mathrm{N}$ to $\mathrm{n}$ ), and both involve the assignment of thematic roles to one or more arguments. Under the Split VP Analysis, V assigns a thematic role to objects (or to the subjects of unaccusative and passive verbs), while $\mathrm{v}$ assigns a thematic role to agentive or experiencer subjects.

The nominal domain appears to work in a similar way. In the German example in 15, the noun Entdeckung 'discovery' has two 
arguments, an agent and a theme. The theme is base-generated in Spec, NP, just as the theme of a verb is base-generated in Spec, VP. N-to-n movement takes place in the same way that V-to-v movement takes place. ${ }^{3}$ Furthermore, again based on example 15, it also seems that at least deverbal nouns lend themselves to an analysis in which agentive subjects are base-generated in Spec, nP, the way agentive subjects of verbs are base-generated in Spec, vP. Even in the case of nondeverbal nouns it is widely believed that $\mathrm{nP}$ parallels vP. Szabolcsi (1994), for example, argues that a possessor in a phrase such as John's house is the subject argument (specifier) of the possessee and is assigned a possessor thematic role by the possessee.

$$
\begin{aligned}
& {\left[{ }_{\mathrm{DP}} \text { Eriksons }_{2 \mathrm{D}}, \quad\left[\mathrm{nP}^{\mathrm{e}} \mathrm{e}_{2 \mathrm{n}} \text {, } \text { Entdeckung }_{1}\left[{ }_{\mathrm{NP}} \text { Amerikas }_{\mathrm{N}} \mathrm{e}_{1}\right]\right]\right]} \\
& \text { Erikson's } \\
& \text { 'Erikson's discovery of America' }
\end{aligned}
$$

A possible issue with placing possessors in Spec, $\mathrm{nP}$ is that possessors are located higher than adjectives, as seen in 16. This only means that the possessor has been raised to a position above APs, namely, Spec, DP. This issue is discussed in section 2.3. Regarding possessors in phrases such as John's house, below I provide evidence that they are base-generated in Spec, NP rather than Spec, nP (Georgi \& Salzmann 2011 also place possessors in Spec, NP).

(16) a. *unerwartete Eriksons Entdeckung Amerikas unexpected Erikson's discovery America's (of America)

b. Eriksons unerwartete Entdeckung Amerikas Erikson's unexpected discovery America's (of America) 'Erikson's unexpected discovery of America'

\footnotetext{
${ }^{3}$ At one time it was common to analyze direct objects as complements of $\mathrm{V}$, but in more recent literature this approach has been abandoned in favor of treating direct objects as specifiers of $\mathrm{V}$. The arguments center around binding issues and ditransitive constructions. For a detailed discussion, see Hornstein et al. 2005, section 3.3.
} 
For the purposes of this article, an important question is whether the verbal and nominal domains are similar in the way case is assigned to subjects. In the verbal domain, objects can be assigned case by the verb, but $\mathrm{v}$ does not assign nominative case to subjects. It is $\mathrm{T} / \mathrm{I}$ that is normally associated with the assigning or valuing of nominative case. The question is whether the nominal domain is similar. Consider again 15 and 16b. Since the object Amerikas follows the head noun Entdeckung, it is reasonable to conclude that it was assigned genitive case by that head noun. The position where case is assigned to the subject Erikson is less transparent. In 16b, Eriksons is in Spec, DP, but that does not mean that it was assigned genitive case there (or in Spec, PossP). It could very well have been assigned case in Spec, nP and moved to Spec, DP for other reasons, such as definiteness, which are discussed shortly. The evidence that an agentive subject can be assigned genitive case within the nominal domain comes from Georgi \& Salzmann 2011:2080:

\section{(17) Die Vorbereitung der Kinder auf das Fest... the preparation the children.GEN on the party 'the children's preparation for the party'}

However, from examples such as this, one cannot conclude whether genitive case can be assigned in Spec, $\mathrm{nP}$. In this example, an agentive subject follows the deverbal noun, which means that the deverbal noun has moved from $\mathrm{N}$ to $\mathrm{n}$, past the subject. The subject is therefore clearly in Spec, NP, not Spec, nP. Example 17, therefore, confirms what has already been established, namely, that genitive case can be assigned in Spec, NP in German. It also shows that there is flexibility in the nominal domain with respect to where an agent can be base-generated: in Spec, $\mathrm{nP}$, as in 15 , or in Spec, NP, as in 17 . Below, I provide evidence that possessors such as the one in John's friends are also base-generated in Spec, NP. This article is therefore ultimately about genitives basegenerated in Spec, NP. The question of whether case can be assigned in Spec, nP, which would indicate asymmetry between the nominal and verbal domains, is not explored here, but it is not central to the arguments presented in this article. 


\subsection{Definiteness and the D-Position.}

Longobardi (1996, 2001) argues that the Germanic and Romance languages differ with respect to the significance of an empty D-node. Following his arguments, Julien $(2003,2005)$ argues that in the Germanic languages, definiteness requires that the D-node-that is, D or Spec, DP-be overtly occupied. This of course means that the D-node in a definite DP has a strong feature that attracts an overt element. I offer the following illustrative examples from German: ${ }^{4}$

(18) a. [DP[-def] $\varnothing_{\mathrm{D}}, \varnothing\left[{ }_{\mathrm{nP}}{ }_{\mathrm{n}}\right.$, Freunde $_{1}\left[\mathrm{NP}\right.$ Johanns $\left.\left.\left._{\mathrm{N}}, \mathrm{t}_{1}\right]\right]\right]$ friends John's

b. [DP[+def] Johanns $2 \mathrm{D}, \varnothing\left[{ }_{\mathrm{nP}} \mathrm{n}\right.$, Freunde $\left.\left._{1}\left[\mathrm{NP}_{2} \mathrm{t}_{2 \mathrm{~N}}, \mathrm{t}_{1}\right]\right]\right]$ John's friends

c. $\left[\mathrm{DP}[+\mathrm{def}] \varnothing_{\mathrm{D}}\right.$, die $\left[\mathrm{nP}_{\mathrm{n}}\right.$, Freunde $_{1}\left[\mathrm{NP}\right.$ Johanns $\left.\left.\left.\mathrm{N}_{\mathrm{N}}, \mathrm{t}_{1}\right]\right]\right]$ the friends John's

In all three examples, the head noun Freunde 'friends' has moved from $\mathrm{N}$ to $\mathrm{n}$. The DP in 18a is indefinite. Consequently, it is not necessary for the D-level to be overtly occupied, and no additional movement takes place. The DPs in 18b,c are definite, and there must be something overt at the D-level. Two strategies are available. In 18b, the genitive form Johanns has moved from Spec, NP to Spec, DP. In $18 \mathrm{c}$, the nP has simply merged with the definite article die. ${ }^{5}$

\footnotetext{
${ }^{4}$ These examples are mine and not taken from Julien, who deals mainly with the Scandinavian languages. My model is consistent with hers. She uses both NP and $\mathrm{nP}$, and she treats possessive adjectives as the head of a PossP basegenerated in Spec, NP.

${ }^{5}$ One might ask if there is a third option to $18 \mathrm{~b}, \mathrm{c}$ in the case of definiteness, namely, the movement of the head noun Freunde 'friends' to D. I would suggest that this option is unavailable for pragmatic reasons. Movement of Freunde to D would result in no change in word order, and it would be impossible to distinguish a definite phrase from an indefinite one. Overt means visible, and Nto-D movement would not produce visible occupation of D in this kind of example.
} 
It is important to emphasize here that in German the genitive case can be assigned in Spec, NP. This is clear from the above examples. However, unlike German, English and Dutch require preposition insertion for case assignment in Spec, NP:

(19) a. Friends *(of) John's

b. Vrienden *(van) Jan friends of John

Note that it is truly the genitive case that is assigned in English, but not in Dutch:

(20) *Vrienden van Jans friends of John's

English seems to still have the vestige of a true genitive case, while Dutch does not. This can be seen from the fact that Dutch does not have the equivalent of the following English genitive forms:

(21) That book is Mary's/hers/ours/theirs/yours.

These genitives probably contain an empty/elided noun as discussed in Sleeman 1996 and Zribi-Hertz 1997. The point I am making here is that English still has this kind of genitive construction, while Dutch does not. I discuss this issue in more detail in section 5.

It is of course well-known that in addition to the genitive with of as in 19a English also has nongenitive PPs with of that have a possessive meaning, for example, the brother of John. Given the semantics of the preposition of, this phenomenon is not surprising. An of-PP without a genitive case is the norm in the Romance languages (Italian $d i$, French $d e$, etc.) and is also possible in Dutch and in German, as seen in 19b and $4 \mathrm{c}$, respectively. Interestingly, there is a certain complementary distribution between of-PPs with and without the Saxon Genitive. The postnominal Saxon Genitive is clearly associated with indefinites, as shown in 22.

(22) a. ?He is the brother of John's.

b. He is a brother of John's. 
c. He is the brother of John.

d. ?He is a brother of John.

Delving too deeply into this matter would go beyond the scope of this paper. This issue is partially addressed in section 5, where I explain why a genitive form is usually prenominal in definite DPs. However, I do not present a complete analysis of the phenomenon illustrated in 22 . I leave this highly relevant topic for future research.

To summarize this subsection, in the Germanic languages, definite DPs require an overt element in D or in Spec, DP. Indefinite DPs (presumably) have a null element in the D position. German allows genitive case assignment in Spec, NP. Dutch and English cannot assign case at the N-level without a preposition. Unlike of, the Dutch preposition van does not assign genitive case but objective or accusative case.

\section{The Saxon Genitive.}

The Saxon Genitive pervades the entire Germanic language family. It cannot be considered to be a typical Indo-European genitive case marking because there are simply too many major differences between the Saxon Genitive and a typical genitive case. In the remainder of this article, I refer to the non-Saxon genitive in the Germanic languages as standard genitive. A detailed discussion of this issue can be found in Weerman \& de Wit 1999 and de Vries 2002. The most relevant difference for the present discussion is that in most Germanic languages, a Saxon Genitive, but not a standard genitive, can attach to an entire phrase, even if the phrase contains a relative clause:

(23) a. My friend who lives in England's house...

b. Teksten som følger-s begynnelse... text-the that follow's beginning 'the beginning of the text that follows'

(Norwegian)

c. Det är mannen som bor bredvid Joachims hund. (Swedish) it is man-the who lives next-to Joachim's dog 'This is the dog of the man who lives next door to Joachim' 
Dutch is very much like English and continental Scandinavian. It also allows the Saxon Genitive to attach to a full DP, but if the DP contains a PP or CP complement, attaching the Saxon Genitive produces marginal results for many speakers:

(24) a. Mijn moeders grootvaders huis... my mother's grandfather's house

b. Jan en Piets huis... John and Pete's house

c. Jan en zijn vrouws huis... John and his wife's house

d. De mans mening... the man's opinion

e. ?De man met de honds mening... the man with the dog's opinion

f. ??De man die ik gezien heb in de stads zus the man that I seen have in the town's sister 'the man that I have seen in the town's sister'

g. *De man die ik in de stad gezien hebs zus the man that I in the town seen have's sister 'the man that I have seen in the town's sister'

The reason why $24 \mathrm{~g}$ is worse than the others probably has to do with the fact that in Dutch, a relative clause is normally strictly verb-final, and the attachment of the Saxon Genitive to a clause-final verb is perceived as a violation of the verb-final rule.

The Saxon Genitive in English, Swedish, and Dutch is somewhat comparable to an ending in an agglutinative language. In the following Hungarian example, none of the individual nominal elements is marked for the dative case. The dative ending simply attaches to the entire DP: 
(25) ...a három nagy kutyá-nak...

the three big dog-DAT

'to the three big dogs'

Unlike the Saxon Genitive in languages such as English, Swedish, Norwegian, and Dutch, the standard genitive case ending does not simply attach to the end of a phrase but involves an agreement operation or feature sharing that affects all the heads in a nominal phrase. In the following German and Latin examples, there is a genitive phrase containing a noun, a demonstrative, and an adjective, and all three elements bear the genitive case:

(26) a. Das Leben [dieses großen Königs]

the life this.GEN great king

'the life of this great king'

b. Vita [huius regis grandis]

life this.GEN king great

'the life of this great king'

It is quite clear that the Saxon Genitive in English, Swedish, Norwegian, and Dutch is not a standard Indo-European genitive case ending. However, what about the $-s$ ending in German? German is the most restrictive of the languages discussed in this paper: The ending $-s$ can attach only to proper nouns with no modifiers or attributes. This already suggests that the Saxon Genitive in German is a true genitive case ending, albeit different from the standard genitive seen in 26a. That the Saxon Genitive in German is different from the standard genitive is most apparent from the fact that it is always $-s$, regardless of whether the possessor is masculine, feminine, or neuter:
a. Vaters Auto...
Father's car
b. Mutters Hut...
Mother's hat 
c. Amerikas Entdeckung durch Erikson... America's discovery by Erikson

There are other differences between the two types of genitive in German. For example, schwa insertion sometimes takes place in standard genitive forms, such as des Kindes versus des Kinds 'of the child'. This type of schwa insertion never occurs with the Saxon Genitive.

The issue becomes especially interesting if one considers the question of where genitive case is assigned. If the German Saxon Genitive is truly a second genitive case, its point of assignment should be Spec, NP. However, this is called into question by the claim in Weerman \& de Wit 1999 and de Vries 2002 that unlike the standard genitive, the German Saxon Genitive is always prenominal and never occurs low:
a. Der Hut der Mutter...
(standard genitive) the hat the.GEN mother 'the hat of the mother'
b. Mutters Hut... mother's hat

(Saxon Genitive)

These authors suggest that in examples such as $4 \mathrm{~b}$ and $8 \mathrm{c}$ (Freunde Johanns) or 15 (Entdeckung Amerikas), the ending on the postnominal genitive forms is not the Saxon Genitive but the standard genitive ending for masculine and neuter nouns. I do not adopt this view, but assume that the standard genitive and the Saxon Genitive can both be assigned in Spec, NP in German and occur postnominally. The sentences in 29, which are admittedly unusual and probably marginal, are certainly not impossible.

(29) a. Wir haben Freunde Mutters eingeladen.

we have friends Mother's invited

'We have invited friends of Mother's.'

b. Das sind alles Freunde Claudias. that are all friends Claudia's. 'Those are all friends of Claudia's.' 
The implication in de Vries 2002 is that phrases such as Freunde Mutters and Freunde Claudias contain a standard (non-Saxon) genitive and are simply borrowing the Saxon Genitive ending because feminine nouns in the standard genitive case are not morphologically marked, as seen in 28a. The following example, which shows a mixture of the standard genitive and the Saxon Genitive, suggests that this might indeed be happening:

(30) das Leben Katharinas der Großen

the life Catherine's the Great

'the life of Catherine the Great'

The noun Katharina is clearly in the Saxon Genitive case, while der Großen is in the standard genitive. Nonetheless, based on the examples in 29, I treat this as inconclusive evidence and assume that the German Saxon Genitive is assigned and can occur postnominally, just like the standard genitive. ${ }^{6}$

There have been (at least) three different approaches in the literature to the Saxon Genitive:

(i) $-s$ is assigned in Spec, DP as a genitive case ending and D is empty, as presented in Szabolcsi 1983 and Abney 1987;

(ii) $-s$ is in D, as in Delsing 1993, 1998, Weerman \& de Wit 1999, de Vries 2002, and den Besten 2006;

(iii) $-s$ is in D in languages such as English, Dutch, and the continental Scandinavian languages, but a case ending in Icelandic and in German, as in Julien 2005 . $^{7}$

\footnotetext{
${ }^{6}$ An interesting approach not pursued here is that there might be only one genitive case in German, whose inflection paradigm is different for proper and common nouns. If this is the case, example 29 is immediately explained. An open question is why genitives of common nouns nearly always follow the noun they modify, while the genitives of proper nouns nearly always precede it.

${ }^{7}$ Julien 2005 deals with the Scandinavian languages and analyzes $-s$ as being in $\mathrm{D}$ in the continental Scandinavian languages but a genitive case ending in
} 
I follow Julien for the following three reasons:

(i) The Saxon Genitive can be assigned at the N-level without preposition insertion in German but not in Dutch and English.

(ii) It attaches to phrases like an agglutinative ending in Dutch and English but not in German.

(iii) Evidence from the study of universal quantifiers, which I discuss in the remainder of this article, indicates that the $-s$ is in D in Dutch and English but not in German.

My approach is to assume that in Dutch and English, $-s$ starts in Poss like a possessive adjective and moves to D. As mentioned in section 2.1, it may well be that PossP is itself located in the specifier position of NP or a functional phrase.

\section{D-Position in Genitive Constructions with Universal Quantifiers.}

4.1. The Inflection on the Universal Quantifier.

Before presenting my own analysis, I need to discuss the nature of D when a genitive phrase occurs in combination with a universal quantifier. German has a rich inflectional system that requires prenominal modifiers to show $\Phi$-feature and case agreement with their head noun. However, unlike other modifiers, a universal quantifier need not be inflected for $\Phi$ features and case as long as there is an overt element in D, such as a definite article, a demonstrative, or a possessive adjective:

(31) a. alle Hunde...

all dogs

b. *all Hunde...

all dogs

c. all die Hunde...

all the dogs

Icelandic. In a personal communication, Julien agreed that the $-s$ in German should be analyzed the same as in Icelandic. 

d. all diese Hunde...
all these dogs
e. all ihre Hunde...
all her dogs

In example $31 \mathrm{a}$, there is no overt element in $\mathrm{D}$, so the quantifier must bear the $-e$ ending. This is confirmed by the ungrammaticality of $31 \mathrm{~b}$. In $31 \mathrm{c}-\mathrm{e}, \mathrm{D}$ is overtly occupied, and there is no inflection on the quantifier. If inflection is added to the quantifier when D is overtly occupied, downgrading or ungrammaticality is often the result. Observe the following examples, which could be either in the nominative or the accusative case and mean 'all the children':
a. all die Kinder
b. all - e Kinder
c. *all
Kinder
d. ?/*alle die Kinder
(no quantifier inflection, definite article) (quantifier inflection, no definite article) (no quantifier inflection, D is empty) (quantifier inflection, definite article)

Many speakers accept the example in $32 \mathrm{~d}$, but many consider it to be ungrammatical. Even speakers who accept it generally prefer 32a,b.

As already mentioned, the examples in 32 are in the nominative or accusative case. The data remain interesting if the dative and genitive cases are examined. The following examples mean 'He has helped all the children'. The verb helfen 'help' takes the dative case:

(33) a. Er hat all den Kindern geholfen. (article, no quantifier inflection) he has all the children helped

b. Er hat all-en Kindern geholfen. (dative quantifier, no article) he has all children helped

c. ?/*Er hat all-en den Kindern geholfen. (quantifier/article in the dative) he has all the children helped

Furthermore, if one examines the genitive case, one can also see that co-occurrence of the inflection on alle and the definite article produces 
marginal results. The following examples mean 'The parents of all the children', and the phrase meaning 'all the children' is in the genitive:

(34) a. (definite article, no quantifier inflection)

die Eltern all der Kinder...

the parents all the.GEN children

'the parents of all the children'

b. (genitive quantifier, no article)

die Eltern all-er Kinder...

the parents all-GEN children

'the parents of all the children'

c. (quantifier and article in the genitive case)

?/*die Eltern all-er der Kinder...

the parents all-GEN the children

Incidentally, the examples in 32-34 would produce similar results if the definite article were replaced with a demonstrative or a possessive adjective, but it must be noted that grammaticality judgments among speakers vary greatly.

At least two issues emerge from these data. First of all, there are ramifications for the claim in Julien 2003, discussed in section 2.3 above, that definiteness requires overt occupation of D or Spec, DP. Since in the b-examples in 32-34 there is no overt element in D or Spec, DP, one might suggest that the universal quantifier compensates for the lack of an overt element in D or Spec, DP. This is not implausible. As argued in Giusti 1990, the universal quantifier is the head of a QP and selects a DP as its complement. The selected DP is always definite, which means that the universal quantifier bears a definite feature. Given this definite feature, and the fact that the quantifier is adjacent to $\mathrm{D}$, it is quite conceivable that the presence of the quantifier satisfies the need for overt occupation of D or Spec, DP, if a DP is definite. Another possibility, as proposed below, is that the inflection on alle is itself an overt D-element that has attached to the quantifier.

The second issue is the question of why inflection on the quantifier is redundant and causes downgrading for many speakers if $\mathrm{D}$ is occupied. 
One might perhaps propose that it has something to do with the fact that the quantifier is not really in DP but in the higher nominal projection QP, and is therefore not subject to the same inflectional requirements as elements in DP. As long as the item occupying D is inflected, that is enough, and any inflection on the quantifier is superfluous and causes downgrading. The problem is that a claim like this is very difficult to defend because there is no independent evidence for it, especially since all heads in a German DP are obligatorily inflected despite redundancy.

Another possibility that comes to mind is that the inflection on the quantifier in the b-examples in 32-34 is simply a definite article that has been phonologically reduced and attached to the quantifier. In other words, the b-examples are the same as the a-examples except that the definite article has been reduced and moved to $Q$ to attach to the quantifier. The definite articles in the c-examples in 32-34 would thus be the spell out of traces or lower copies, and this could be what causes the downgrading. The problem with this idea is that it does not explain where the inflection on a quantifier comes from if something other than the definite article occupies D. Consider the following phrases:

$$
\begin{aligned}
& \text { a. */?alle diese Bücher... } \\
& \text { all these books } \\
& \text { b. */?alle meine Bücher... } \\
& \text { all my books }
\end{aligned}
$$

These examples are a bit downgraded for some speakers but are certainly possible. One would not want to claim that the $-e$ on the quantifier in these examples is a reduced definite article, since definite articles do not co-occur with demonstratives or possessive adjectives. One would also not want to say that the $-e$ is a reduced demonstrative in $35 \mathrm{a}$ and a reduced possessive adjective in $35 \mathrm{~b}$ : These two categories do not lend themselves to reduction, given that they bear more semantic weight than a definite article and are bi-syllabic.

To quickly recapitulate the last few paragraphs, two issues need to be addressed. First, the data in $31 \mathrm{a}, 32 \mathrm{~b}, 33 \mathrm{~b}$, and $34 \mathrm{~b}$ seem to contradict the well-established principle in Julien 2003 that in a definite DP, an overt element must occupy D or Spec, DP. Second, the data in $32 d, 33 c, 34 c$, and $35 \mathrm{a}, \mathrm{b}$ show that the co-occurrence of an overt element in $\mathrm{D}$ and 
inflection on the quantifier create marginal results, and the reason is not clear. What I propose is that both of these issues are resolved if the inflection on the quantifier is analyzed as an overt D-element that has moved up and attached to the quantifier. This would immediately explain why $31 \mathrm{a}, 32 \mathrm{~b}, 33 \mathrm{~b}$, and $34 \mathrm{~b}$ are grammatical. It would also offer an explanation for the marginality of $32 \mathrm{~d}, 33 \mathrm{c}, 34 \mathrm{c}$, and $35 \mathrm{a}, \mathrm{b}$ because the -e ending and the other overt D-element (definite article, possessive adjective, and demonstrative) would be competing for the D-position, producing a doubling effect.

If the $-e$ ending is a D-element, what is it exactly? As already discussed, one does not want to claim that it is a reduced definite article, possessive adjective, or demonstrative. The best idea that comes to mind is that the $-e$ ending on the quantifier is the phonetic realization of the definiteness feature on $\mathrm{D}$, and that it moves up and attaches to the quantifier. How such a derivation works is briefly discussed in section 4.4. First, however, several other issues must be discussed.

\subsection{Two Elements in D.}

The claim that $-e$ (-en or -er, depending on case) is a D-element implies that in $32 \mathrm{~d}, 33 \mathrm{c}, 34 \mathrm{c}$, and $35 \mathrm{a}, \mathrm{b}$ there are two elements in D. Is this plausible? There is in fact very good evidence that $\mathrm{D}$ can be occupied by more than one element in German. Consider examples such as the following, which are well-known to Germanicists:

(36) a. diese meine guten Freunde...

these my good friends

'these good friends of mine'

b. dieses mein großes Glück...

this my great fortune

'this great fortune of mine'

One way to analyze these sentences would be to say that the possessive adjective has not moved to $\mathrm{D}$, which is occupied by a demonstrative. I reject this analysis for very good empirical reasons. In 36a, for example, if the possessive adjective meine had not moved to D and were still in its adjectival position, it would have to be inflected with a weak/secondary ending yielding the ungrammatical *diese meinen guten Freunde. 
Example $36 \mathrm{~b}$ is even more interesting. If the demonstrative were the sole occupier of $\mathrm{D}$, there would have to be a weak/secondary ending on both the possessive adjective and the adjective gro $\beta$, producing the ungrammatical *dieses meine große Glück. If one posits a compound formed by movement of the possessive adjective to D and having it rightadjoin to the demonstrative, the inflection in both sentences in 36 is readily explained.

One might say that in the sentences in 36 , the possessive adjective occupies D and the demonstrative is an independent DP that is simply in apposition to the DP headed by the possessive adjective. This explanation does not work. For example, if $36 \mathrm{~b}$ consisted of two appositive DPs, these DPs would be separated by a slight pause - which they are not-and the demonstrative dieses would appear in the pronominal form dies. The best explanation for 35 and 36 is the doubleoccupation of $\mathrm{D}$. In the next subsection, I provide more evidence that $-e$ is a D-element.

\subsection{Additional Evidence that -e Behaves Like a D-Element.}

I now present additional evidence that the $-e$ on alle is a D-element in German and Dutch. I begin with German, in which the inflection on the quantifier has the same morphological effect on adjectives that follow it as the plural definite article has. They both trigger the weak $-n$ ending:

(37) a. all die guten Menschen...

all the good people

(full article)

b. all-e guten Menschen

all good people

(quantifier inflection, no article)

c. ?/*all-e die guten Menschen all the good people

(article and quantifier inflection)

If there is no overt element in $\mathrm{D}$ in a plural context, there is no weak/secondary morphology. This is seen in the following example, in which $\mathrm{D}$ is empty, and the adjective bears a strong/primary ending: 
(38) Kluge/*Klugen Menschen haben mit Syntax nichts $\mathrm{zu}$ tun. clever people have with syntax nothing to do 'Clever people have nothing to do with syntax.'

Another way of saying this is that the combination of definiteness and an occupied D position means weak/secondary inflection in a plural context: ${ }^{8}$

(39) seine besten Freunde...

his best friends

These examples demonstrate the D-like characteristics of the inflection on the quantifier. Genitive phrases in German do not have this quality. In the case of a prenominal Saxon or non-Saxon/standard genitive, both of which signify definiteness, D is probably empty. Otherwise, there would be weak morphology on the adjectives in the following examples:

(40) a. Marias schönste/*schönsten Gemälde... Maria's most beautiful paintings...

b. des Königs treuste/*treusten Diener... the king's most faithful servants

The example in 40a contains a Saxon genitive, the example in $40 \mathrm{~b}$ a nonSaxon genitive. Based on the data just presented, I conclude that the $-e$ ending on alle in German originates in $\mathrm{D}$ and moves to $\mathrm{Q}$ to attach to the quantifier. In contrast, prenominal genitive endings, Saxon and non-

\footnotetext{
${ }^{8}$ Things are different in a singular context. A singular definite article-like a plural definite article - generates weak/secondary morphology on an adjective, as in das große/*großes Haus 'the big house' and die großen/*große Häuser 'the big houses'. However, a singular masculine or neuter possessive adjective, unlike its plural counterpart, generates strong/primary morphology on an adjective: mein großes/*große Haus 'my big house'. This is probably due to the fact that the masculine and neuter singular possessive adjectives bear no inflection in the nominative case, and one strong ending is required in the derivation.
} 
Saxon, are not in D but in Spec, DP, along with the noun that they are attached to.

I now demonstrate that in Dutch, the -e ending on alle also originates in D, but the Saxon Genitive ending is in D, not Spec, DP as it is in German. I begin with the Dutch examples in 41 .

(41) a. al de goede mannen (definite article, no quantifier inflection) all the good men

b. all-e goede mannen all-INFL good men

(quantifier inflection, no article) 'all the good men'

c. *all-e de (goede) mannen all-INFL the (good) men

(doubling)

d. *al (goede) mannen (D is empty, no quantifier inflection) all (good) men

Dutch does not have as rich a nominal inflectional system as German, but it has certainly not lost its nominal inflectional system, and it is practically identical to German in the way it handles the inflection of the universal quantifier. Both languages require either inflection of the quantifier or an element in D. As seen in 41c, Dutch is even stricter than German on the co-occurrence of the definite article and the inflection on alle. That is, whereas 41c produces marginal results in German for many speakers, it is consistently ungrammatical in Dutch. The ungrammaticality of this "doubling" implies that the $-e$ ending on alle is in D in Dutch, just as it is in German.

The following two examples provide evidence that the Saxon Genitive ending is in D in Dutch:

(42) a. al Jans vrienden...

all John's friends

b. *all-e Jans vrienden... all-INFL John's friends 
Example 41d shows that in a definite phrase with a universal quantifier, $\mathrm{D}$ needs an overt element. Example 42a is grammatical because the Saxon Genitive ending is in $\mathrm{D}$, which means that inflection of the quantifier is unnecessary. I am proposing that $42 \mathrm{~b}$ is ungrammatical because there are two elements competing for the D position: the $-s$ and the element that has become the inflection on alle.

One question that arises here is why there is one instance in which English does not require an overt element in a definite DP, which is impossible in German and Dutch:

(43) a. all friends

b. *al vrienden...

(Dutch)

c. *all Freunde...

(German)

German and Dutch, unlike English, are both inflectional languages in the nominal domain, and some type of marking is necessary. This is one reason why the German and Dutch examples in 43 are not possible, while the English one is. The other reason why the German and Dutch examples are ungrammatical is, of course, that there is no overt element in D. However, this raises the question of why the English example is possible in the absence of an overt element in D. I treat this as an English-specific issue that requires future research, but conjecture that it has to do with the lack of any kind of nominal inflection in English.

Given that $43 \mathrm{~b}$ is ungrammatical because Dutch requires inflection in the nominal domain, one may ask why the phrase al mijn vrienden 'all my friends', in which there is no inflection on the quantifier or the possessive adjective, is grammatical. There is an explanation. No inflection is needed on the quantifier because, as already mentioned, the possessive adjective mijn occupies D. No inflection is visible on the possessive adjective mijn for the simple reason that this possessive adjective, unlike other adjectives, is not inflected: mijn vriend 'my friend' and mijn vrienden 'my friends'.

\subsection{Mechanics of the Phonetic Realization of the Definiteness on D.}

When the definiteness feature on $\mathrm{D}$ is phonetically realized, the derivation proceeds as follows: The universal quantifier selects definite DPs, and the definiteness feature on D is phonetically realized as $-e$ in German and Dutch but remains unrealized in English, which is totally 
non-inflectional. (The $-e$ ending will of course vary as -en or -er, according to which case it is assigned.) After the universal quantifier has selected a definite DP and the definiteness feature has been phonetically realized as $-e$, one of the following scenarios is possible:

(i) If there is no other element in $\mathrm{D}$ (no determiner, no possessive adjective, no demonstrative), $-e$ will attach to the quantifier:
all-e Hunde
(German)
all-e honden
(Dutch) all-INFL dogs all-INFL dogs

(ii) If there is an overt element in $\mathrm{D}$, (a determiner, possessive adjective, or demonstrative), the $-e$ ending is optionally but preferably deleted in German and obligatorily deleted in Dutch:
all(e) die Hunde (German) all(INFL) the dogs
al de honden all the dogs
(Dutch)

(iii) If $-e$ is not deleted (possible only in German), it is raised to the quantifier. This unusual procedure produces downgrading for many speakers:
?/*alle die Hunde (German) all the dogs
*all-e de honden (Dutch) all-INFL the dogs

Thus, analyzing -e as a D-element can explain the behavior of universal quantifiers in German and Dutch.

\subsection{Summary.}

To briefly summarize this section, the inflection on the universal quantifier in both Dutch and German shows all signs of being a Delement. I have proposed that it is the phonetic realization of the definiteness feature on D. I have argued that the $-e$ ending can co-occur with another D-element in German, such as a determiner, a possessive adjective, or a demonstrative, which produces, for many speakers, a doubling effect. As a result, phrases such as alle seine Freunde 'all his friends' are perceived as marginal. My claim that $-e$ can co-occur with another D-element is supported by evidence that more than one element 
can occupy D in German. Finally, although the $-e$ ending is the same in German and Dutch, the two languages differ with regard to the Saxon Genitive. The Saxon Genitive ending is in D in Dutch but not in German, where it is a true case ending located in Spec, DP, with the possessor it attaches to.

\section{Explaining the Difference Between German, Dutch, and English.}

As mentioned in the Introduction, the aim of this article is to explain the following discrepancy:

(44) a. all John's friends

b. al Jans vrienden

(Dutch)

c. *all(e) Johanns Freunde

(German)

I begin with the base structure of the German sentence in $44 \mathrm{c}$, in which the inflection on the quantifier alle is glossed as the definiteness feature:

$$
\begin{aligned}
& \text { [QP Q, all [DP D, -e [ } \left.\left.\left.{ }^{n P} n^{\prime} \text { Freunde }_{1}\left[{ }_{N P} \text { Johanns }_{\mathrm{N}}, \mathrm{t}_{1}\right]\right]\right]\right] \\
& \text { all DEF friends John's }
\end{aligned}
$$

As has already been implied in the above discussion, there are two reasons, stated in 46 , for why a possessor might move to the D-level.

(46) a. Definiteness requires that either D or [Spec, DP] be overtly occupied.

b. The possessor must be assigned case.

In the German example in 44, neither of these two reasons is present. The quantifier contains inflection, which I claim is a D-element, and the possessor has already been assigned genitive case in Spec, NP. Example $44 \mathrm{c}$ is ungrammatical because there is no motivation for the movement of the genitive phrase to the D-level.

Before discussing Dutch and English, I would like to briefly comment on genitives and floating quantifiers in German. Note the following sentences: 
(47) a. *All(e) Johanns Freunde sind dumm. All(INFL) John's friends are dumb.

b. Johanns Freunde sind all-e dumm. John's friends are all-INFL dumb.

The $47 \mathrm{a}$ example is ungrammatical, but it becomes grammatical if the quantifier is floated, as seen in the $47 \mathrm{~b}$ example. This might seem to be evidence against the Stranding Analysis of floating quantifiers initiated by Sportiche (1988) and Giusti (1990). However, it is actually evidence in favor of the present analysis and the Stranding Analysis. Under the Stranding Analysis, the universal quantifier is the head of a QP and selects a definite DP as its complement. The entire QP can of course move to subject position, but the DP can also move by itself and strand the quantifier in $\mathrm{vP} / \mathrm{VP}$. In $47 \mathrm{a}$, the entire $\mathrm{QP}$ has moved to Spec, TP. The possessor Johann has moved to a position above nP, presumably Spec, DP. The result is ungrammatical because the D-node is overtly occupied through the presence of the $-e$ ending on alle, and movement of the possessor is thus unnecessary. The derivation is "rescued" in $47 \mathrm{~b}$ by stranding the quantifier. That is, since the quantifier is stranded in $\mathrm{vP}$, there is no longer anything visible at the D-level in the definite DP. The possessor's presence in Spec, DP in $47 \mathrm{~b}$ is thus not only possible but necessary. The mechanics of this derivation need to be worked out, but there is a strong indication that the need for overt occupancy of the Dnode is what allows the prenominal positioning of the possessor in $47 \mathrm{~b}$, in which the quantifier (and the $-e$ inflection on it) has been stranded.

I turn now to Dutch, in which both reasons in 46 for why a possessor might move to the $\mathrm{D}$ level are potentially present. I begin with a base structure such as the following:

$$
\begin{aligned}
& \text { [QP Q'al [DP D' [ } \left.\left.{ }^{\prime} n^{\prime} \operatorname{vrienden}_{1}\left[{ }_{N P} \operatorname{Jan}_{\mathrm{N}}, \mathrm{t}_{1}\right]\right]\right] \\
& \text { all friends John }
\end{aligned}
$$

In this base structure, there is no overt element in D (and no inflection on the quantifier), and the possessor Jan has not been assigned case, since, unlike German, Dutch does not allow case assignment in Spec, NP. There are two strategies available, given this base structure: 
(49) a. [QP Q,al [DP D, -e [nP n, $\left.\left.\operatorname{vrienden}_{1}\left[\mathrm{NP} \operatorname{van~Jan~}_{\mathrm{N}}, \mathrm{t}_{1}\right]\right]\right]$ all friends of John

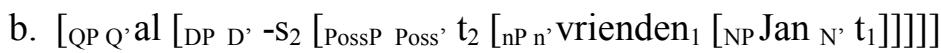
all friends John

The strategy in 49a is to assign case by insertion of the preposition van 'of' and merge $\mathrm{nP}$ with the inflection on the quantifier, which I have argued is a $\mathrm{D}$ element. The result is alle vrienden van Jan 'all friends of John' (nP could also have merged with a normal definite article, producing al de vrienden van Jan 'all the friends of John'). The strategy in $49 \mathrm{~b}$ is not to assign case in Spec, NP and merge nP with the Saxon Genitive. The Saxon Genitive in turn attracts the possessor Jan to Spec, PossP and attaches to it.

This movement of the possessor to Spec, PossP could be motivated by a number of factors. It could be because the possessor needs to be assigned case; it could also be because the $-s$ ending is like a clitic that needs to attach to another element; it could be because the $-s$ ending is anaphoric and needs to be bound by the possessor; finally, it could be that $-s$ has an EPP feature that draws the possessor to it like a subject. This last option is consistent with the proposal in Georgi \& Salzmann 2011 that in German possessive dative constructions the third person possessive adjective has an EPP feature that attracts the possessor to its specifier position. Having combined with the Saxon Genitive, the possessor moves, along with the Saxon genitive attached to it, to Spec, DP, to satisfy the requirement that the D node be occupied in a definite DP.

English, which is inflectionally weaker than Dutch, has no inflection on a quantifier. Consider the following base structure, in which friends has moved from $\mathrm{N}$ to $\mathrm{n}$ :

(50) $\left[\mathrm{QP} Q\right.$, all [DP D, [nP n, friends $\left.\left.{ }_{1}\left[\mathrm{NP}_{\mathrm{Nohn}}, \mathrm{t}_{1}\right]\right]\right]$

The following strategies are available:

(51) a. [QP Q, all [DP D' (the) [nP n' friends ${ }_{1}\left[\mathrm{NP}\right.$ of John's $\left.\left.\left.\mathrm{N}_{\mathrm{N}}, \mathrm{t}_{1}\right]\right]\right]$

b. [QP Q, all [DP D, $-\mathrm{s}_{2}\left[\right.$ PossP Poss' $\mathrm{t}_{2}\left[\mathrm{nP}_{\mathrm{n}}\right.$, friends $\left.\left.\left.\left._{1}\left[\mathrm{NP} \mathrm{JOhn}_{\mathrm{N}}, \mathrm{t}_{1}\right]\right]\right]\right]\right]$ 
The strategy in 51a is to assign genitive case to the possessor by preposition insertion. The $\mathrm{nP}$ can merge with the definite article the. However, as mentioned in section 4.3, for reasons that are not completely understood English allows the universal quantifier to merge with a definite DP that contains no overt D-element at all. The other strategy, in $51 \mathrm{~b}$, is to forgo preposition insertion and to merge $\mathrm{nP}$ with the Saxon Genitive in Poss. The possessor moves to Spec, PossP to combine with the Saxon Genitive and then follows the same derivational steps just shown for Dutch.

Note that the Saxon Genitive in Dutch and English is a kind of hybrid: It is not a real case, but it is able to function as a case, satisfying the need for case on possessors (like an agglutinative ending). This is not particularly surprising given the widely accepted hypothesis that the Saxon Genitive began as a genitive ending and has evolved into a type of clitic determiner.

Note also that I am claiming here, as I did in section 2.3 , that English, unlike Dutch, still has a genitive that can be assigned by preposition insertion in Spec, NP. This is evidenced by phrases such as the following, which are not found in Dutch:

(52) A friend of John's/mine/thine/yours/his/hers/ours/theirs...

The fact that two of these forms, mine and thine, do not end in $-s$ suggests that in the case of the possessive pronouns, one is not dealing with a Saxon Genitive.

There is one potential problem with the analysis proposed here: For some English speakers, the strategy in $51 \mathrm{a}$, whereby a genitive phrase merges with the definite article, produces marginal results:

*/?...all the friends of John's

This issue is discussed in Kayne 1994:86. According to Kayne, a phrase such as 53 becomes acceptable if modified by a restrictive relative clause. His examples 5 and 6 are provided below:

(54) a. */?...the two pictures of John's...

b. ...the two pictures of John's/his that you lent me... 
Kayne explains this as follows: A genitive phrase has a base structure with the possessor in Spec, NP, which is not unusual. However, in order to produce a postnominal possessor, starting with the base word order in 55a, Kayne moves the phrase two pictures past the possessor to Spec, DP, which produces two pictures of John's. Structure 55a is ruled out because if two pictures is in Spec, DP, then the has selected a DP complement, which should not be possible, as D selects NP, not DP. Example $54 \mathrm{~b}$, with the base structure in $55 \mathrm{~b}$, is possible because it involves a restrictive relative clause base-generated prenominally below D.

a. [the [[DP of John's [two pictures]]]]

b. [the [CP [that you lent me] [of John's [two pictures]]]]

The phrase two pictures moves to a specifier position to the left of the possessor. The resultant two pictures of John's then moves to the specifier position of the CP that you lent me, which is headed by that. In this way, Kayne argues, D is not selecting DP but CP, and the derivation is felicitous.

There are problems with this approach. First of all, Kayne's analysis does not consider the effects of the Split NP Hypothesis, which creates additional positions within the nominal domain. Second, as Kayne himself points out, many English speakers do not reject the construction in 54a. Third, Kayne's argumentation is too English-specific. German and Dutch have no problem at all with the word order in 53:

$$
\begin{aligned}
& \text { a. ... all die Freunde Johanns } \\
& \text { all the friends John's } \\
& \text { 'all the friends of John's' } \\
& \text { b. ... al de vrienden van Jan } \\
& \text { all the friends of John }
\end{aligned}
$$

For those speakers who reject 54a, I suspect that a conflict is produced by the combination of the definite article and a postnominal genitive, ordinarily associated with indefiniteness.

The gist of this section, then, is that the discrepancy in 44 is due to three facts. First, the Saxon Genitive is a true case ending in German, 
assigned in NP, but it is more like a possessive adjective in Dutch and English. Second, the genitive case, including the Saxon Genitive, is assigned low in German, but not in Dutch and English. This necessitates movement of a possessor in Dutch and English to Spec, PossP and Spec, $\mathrm{DP}$, if a preposition is not inserted. Third, movement of a possessor to Spec, DP is only necessary if in a definite phrase there is no overt element in D or Spec, DP. If there is an overt element in D, movement cannot take place.

\section{Dative of Possession/Possessor Doubling Constructions.}

As shown in section 1, dative of possession constructions, often referred to as possessor doubling, are found throughout the Germanic language family. The most famous example is the following sentence from German:

(57) Der Dativ ist dem Genitiv sein Tod.

the dative is the genitive its death

'The dative is the genitive's death.'

What is amusing about this sentence is that the word Genitiv is in the dative case instead of the genitive case, which adds insult to injury for the threatened genitive case.

In this section, I consider possessive dative constructions that involve a universal quantifier. Observe the following example from Kölsch, in which the possessor is in the dative case:

Ich han all däm Pitter sing Frönde enjelade.

I have all the.DAT Peter his friends invited

'I have invited all Peter's friends.'

The base structure for this example would be as follows:

(59) [QP Q, all [DP D' sing 2 [PossP Poss' $t_{2}\left[{ }_{n P}\right.$, Frönde $_{1}\left[{ }_{N P} d-\right.$ Pitter $\left.\left.\left.\left._{N}, t_{1}\right]\right]\right]\right]$ all his friends the Peter

In this phrase, the noun Frönde has moved from $\mathrm{N}$ to $\mathrm{n}$, and the possessive adjective sing from Poss to D. The possessor, which is going to move to Spec, DP via Spec, PossP, is base-generated in Spec, NP, just 
like a possessor in a genitive phrase. Two questions are posed by these data. The first question is why a dative possessor like the one in 58 can move to a position immediately after a universal quantifier, while a genitive possessor cannot. If one follows, as I do, the arguments in Georgi \& Salzmann 2011, whereby dative case in German possessive dative constructions is assigned in Spec, NP (like the genitive), then one must assume that the movement of the possessor in 58 has nothing to do with case assignment.

The second question is why in German the possessive adjective can co-occur with dative possessors, as in 57 and 58, but never with possessor DPs in the genitive:

(60) a. *Seine Freunde Johanns...

his friends John.GEN

b. *Johanns seine Freunde... John.GEN his friends

c. *Seine Johanns Freunde... his John's friends

The answers to both of these questions can be found in the discussion of dative possessives in Georgi \& Salzmann 2011, although that article does not address the issue of universal quantifiers and possessors. In Georgi \& Salzmann's analysis, the possessive adjective (referred to as a possessive pronoun) bears a dative feature, so that it can only select DPs that have been assigned dative case in Spec, NP. This excludes examples with a genitive possessor, such as 60 . Furthermore, continuing with Georgi \& Salzmann's analysis, the possessive adjective has an EPP feature that draws the dative possessor to its specifier position. Georgi \& Salzmann thus inadvertently provide an explanation for why a dative possessor can move to Spec, DP in the presence of a universal quantifier, while a genitive possessor cannot. Incidentally, Georgi \& Salzmann also treat the possessive adjective as being anaphoric, which means that it requires a c-commanding, co-indexed antecedent. The movement of the possessor to the specifier position of the possessive adjective satisfies this requirement. 
One last question I would like to discuss here is what determines whether a head noun (possessee) assigns dative or genitive case to its possessor in Spec, NP. I suggest that in Standard German, this is dependent upon which register a speaker is employing. The possessive dative is associated with an informal register. The same principle applies to regional languages such as Kölsch, Swabian, and others, in which the possessive dative is very often the preferred manner of expressing possession, and the genitive case is ignored (as implied in the humorous example in 57).

There is one last relevant fact regarding the sentence in 58. Movement of the dative possessor to a position above the universal quantifier is not possible in Dutch, but it is possible, with marginal results, in Kölsch:

(61) a. Ik heb al Piet z'n vrienden uitgenodigd.

(Dutch)

I have all Pete his friends invited

'I have invited all of Pete's friends.'

b. *Ik heb Piet al z'n vrienden uitgenodigd.

I have Pete all his friends invited

c. Ich han all däm Pitter sing Frönde enjelade.

(Kölsch)

I have all the.DAT Peter his friends invited 'I have invited all of Peter's friends.'

d. ?Ich han däm Pitter all sing Frönde enjelade. I have the.DAT Peter all his friends invited

These data show that in Kölsch, the dative possessor can move to a position higher than Spec, DP, such as Spec, QP, or perhaps to a topicalization position inside the nominal domain. The question of why this is not possible in Dutch is left for future research; however, it is quite plausible that case marking is a factor. The only real difference between Dutch and Kölsch in this construction is that there is no overt marking for dative in Dutch, but there is in Kölsch. 


\section{Summary and Potential Areas of Future Research.}

The principal aim of this article has been to explain why German, unlike Dutch and English, does not allow a genitive phrase to follow a universal quantifier. This difference in the West Germanic language family has been explained on the basis of the following arguments:

(i) As demonstrated in Julien 2003, 2005, in the Germanic languages a definite DP requires that its D-node (D or Spec, DP) be overtly occupied.

(ii) In German, the Saxon Genitive is a true case ending assigned in Spec, NP, while in Dutch and English, it is more like a possessive adjective that originates in Poss and moves to $\mathrm{D}$.

(iii) The -e ending on alle behaves like a D-element in German and Dutch. It is very possibly the phonetic realization of the definiteness feature on D, and it can occupy D when D is occupied by another element. Evidence that $\mathrm{D}$ can be occupied by more than one element in German is seen in phrases such as diese meine guten Freunde 'these my good friends' and dieses mein großes Glück 'this my great fortune'.

(iv) Possessors, which originate in Spec, NP, move via Spec, PossP to Spec, DP if they need case, or if the phrase is definite and there is no overt element at the D-level. Otherwise, movement does not take place.

(v) In German, the genitive case can be assigned in Spec, NP. Therefore, the only reason for a genitive possessor to move to the D-level in German is if the DP is definite and no overt element is occupying the D-node. In Dutch and English, where the genitive cannot be assigned by $\mathrm{N}$, case assignment can be an additional motivation for movement of a possessor to the D-level, in addition to the need for overt occupation of the D-node.

The fact that in German, a dative of possession can follow a universal quantifier, while a genitive possessor cannot, follows from arguments in Georgi \& Salzmann 2011 regarding the nature of dative possessors. In 
particular, dative possessors co-occur with possessive adjectives. The possessive adjectives have an EPP feature and are anaphoric, which will cause them to draw a possessor to their specifier position.

A number of issues have been left for future research. In section 2.2, I raised the question of whether case can be assigned in Spec, nP although case cannot be assigned in Spec, vP. Empirical evidence is inconclusive. In section 2.3, I pointed out that in English, a prepositional possessive in the genitive case is much more felicitous in an indefinite phrase than a definite phrase (a friend of John's sounds much better than a friend of John). In contrast, a prepositional possessive without genitive marking is more felicitous in a definite phrase (the friend of John sounds better than the friend of John's). In section 4.1, I proposed that the -e ending on the universal quantifier in German and Dutch could be the phonetic realization of the definiteness feature on $\mathrm{D}$, and that this should be further investigated. In section 4.3, I left unresolved the question of why English allows phrases such as all friends, a definite DP with no apparent overt element in D or Spec, DP. In section 6, example 61d, I raised the question of why a dative possessor can move above a quantifier in Kölsch but not in Dutch, and suggested that it might have to do with overt marking of the dative case.

In conclusion, I would like to point out that an analysis of the Scandinavian languages within the theoretical framework proposed here could be fruitful. Icelandic, which has a much more elaborate inflectional system than its continental sisters, seems to differ from the continental Scandinavian languages in the same way that German differs from Dutch and English when a genitive is combined with a universal quantifier. That is, a Saxon Genitive following a universal quantifier is perfectly normal in the continental Scandinavian languages, whereas it sounds antiquated in Icelandic:

(62) a. Allir vinir Jóns...

(Icelandic)

all friends John's

'all friends of John's'

b. ?Allir Jóns vinir...

all John's friends 
c. Alla Johans vänner...

(Swedish) all Johan's friends

This and other aspects of the combination of the Saxon Genitive and the universal quantifier in Scandinavian would be worth exploring.

\section{REFERENCES}

Abney, Steven P. 1987. The English noun phrase in its sentential aspect. Cambridge, MA: MIT dissertation.

Adger, David. 2003. Core syntax: A minimalist approach. Oxford: Oxford University Press.

Besten, Hans den. 2006. The origins of the Afrikaans pre-nominal possessive system(s). Studies in contact linguistics: Essays in honor of Glenn G. Gilbert, ed. by Linda L. Thornburg \& Janet M. Fuller, 91-104. New York, NY: Peter Lang Publishing Inc.

Cardinaletti, Anna. 1998. On the deficient/strong position in possessive systems. Possessors, predicates and movement in the determiner phrase, ed. by Artemis Alexiadou \& Chris Wilder, 17-53. Amsterdam, Philadelphia: John Benjamins.

Cinque, Guglielmo. 2010. The syntax of adjectives: A comparative study (Linguistic Inquiry Monograph 57). Cambridge, MA: MIT Press.

Cirillo, Robert. 2015. Why all John's friends are Dutch, not German: On differences in West Germanic in the interaction between universal quantifiers and genitives. Bucharest Working Papers in Linguistics 2014, 16. 47-68.

Delsing, Lars-Olof. 1993. The internal structure of noun phrases in the Scandinavian languages: A comparative study. Lund: Department of Scandinavian Languages, University of Lund.

Delsing, Lars-Olof. 1998. Possession in Germanic. Possessors, predicates and movement in the determiner phrase, ed. by Artemis Alexiadou \& Chris Wilder, 87-108. Amsterdam/Philadelphia: John Benjamins.

Dobrovie-Sorin, Carmen, \& Ion Giurgea. 2011. Pronominal possessors and feature uniqueness. Language 87. 127-157.

Georgi, Doreen, \& Martin Salzmann. 2011. DP-internal double agreement is not double Agree: Consequences of Agree-based case assignment within DP. Lingua 121. 2069-2088.

Giusti, Giuliana. 1990. Floating quantifiers, scrambling and configurationality. Linguistic Inquiry 21. 633-641.

Hornstein, Norbert, Jairo Nunes, \& Kleanthes K. Grohmann. 2005. Understanding minimalism. Cambridge: Cambridge University Press. 
Julien, Marit. 2003. Double definiteness in Scandinavian. Proceedings of the Nineteenth Scandinavian Conference of Linguistics (Introduction to Nordlyd 31), ed. by Anne Dahl, Kristine Bentzen, \& Peter Svenonius, 230-244. Tromsø: The University of Tromsø, Serpentino Academic Publishing. Julien, Marit. 2005. Nominal phrases from a Scandinavian perspective. Amsterdam: John Benjamins.

Kayne, Richard. 1994. The Antisymmetry of Syntax. Cambridge, MA: MIT Press.

Larson, Richard. 1988. On the double object construction. Linguistic Inquiry 19. 335-391.

Longobardi, Giuseppe. 1996. The syntax of N-raising: A minimalist theory (Onderzoekinstituut voor Taal en Spraak Working Papers 5). Utrecht: University of Utrecht.

Longobardi, Giuseppe. 2001. How comparative is semantics? A unified parametric theory of bare nouns and proper names. Natural Language Semantics 9. 335-9369.

Longobardi, Giuseppe, \& Giuseppina Silvestri. 2012. The structure of noun phrases: Some insights on Case, empty categories and poverty of the stimulus. The Bloomsbury companion to syntax (Continuum Companion Series), ed. by Silvia Luraghi \& Claudia Parodi, 88-117. London: Bloomsbury Academic. Norris, Mark. 2011. Extraposition and definiteness effects in Icelandic DPs. Morphology at Santa Cruz: Papers in Honor of Jorge Hankamer, ed. by Nicholas LaCara, Anie Thompson, \& Matthew A. Tucker, 97-121. Santa Cruz, CA: Linguistics Research Center, University of California Santa Cruz. Radford, Andrew. 2004. English syntax: An introduction. Cambridge: Cambridge University Press.

Sleeman, Petra. 1996. Licensing empty nouns in French. Amsterdam, The Netherlands: University of Amsterdam dissertation.

Sportiche, Dominique. 1988. A theory of floating quantifiers and its corollaries for constituent structure. Linguistic Inquiry 19. 425-449.

Szabolcsi, Anna. 1983. The possessor that ran away from home. The Linguistic Review 3. 89-102.

Szabolcsi, Anna. 1994. The noun phrase. The syntactic structure of Hungarian (Syntax and Semantics 27), ed. by Ferenc Kiefer \& Katalin É. Kiss, 179-231. San Diego, CA: Academic Press.

Thráinsson (Práinsson), Höskuldur. 2007. The syntax of Icelandic. New York, NY: Cambridge University Press.

Vries, Mark de. 2002. The syntax of relativization. Amsterdam, The Netherlands: University of Amsterdam dissertation.

Weerman, Fred, \& Petra de Wit. 1999. The decline of the genitive in Dutch. Linguistics 37. 1155-1192. 
218 Cirillo

Zribi-Hertz, Anne. 1997. On the dual nature of the 'possessive' marker in Modern English. Journal of Linguistics 33. 511-537.

Milletstraat 16-1

1077 ZD Amsterdam

The Netherlands

[ciri1000@planet.nl] 